\title{
The Troublesome Ghosts: Part 2
}

妖魔，第二部

\section{The Lowest-Ranked Ghosts}

Ghosts are, in general, troublesome creatures. The lower ranks of the Daoist hierarchy of spirits includes many ghosts. Someone who is being harassed by ghosts can call for help from a spirit general. Sometimes, former generals who were heroic in life are honored as spirit generals after their death and are given the title prime marshal [yuanshuai 元帥]. These spirits can carry messages from Daoist masters on earth who are human beings to the deities in the heavens. They are also responsible for security and the protection of the celestial realms. They command thousands of ghost soldiers, who can be ordered to attack the ghosts and demons who are causing trouble for human beings.

One text I bought is titled Eight Effective Formulas [Ba qinkoujue 八親 $\square$ 決]. ${ }^{1}$ It was written and illustrated in October 1904 and is filled with incantations calling upon spirit generals and their troops and horses for help in dealing with unwanted ghosts and evil forces. In order to marshal these spirit forces, in the course of a ceremony a Daoist ritual master would bang on the alter a wooden "command placard" [lingpai 令牌] block as a sign of his issuing an order to the spirits. A lingpai I bought in December 2014 that was made in Changsha 長沙 perfectly illustrates its function. It is $5^{-1} / 8$ inches $(13 \mathrm{~cm})$ high and a little over 2 inches $(6 \mathrm{~cm})$ wide, with a square base representing the earth and a rounded top representing the heavens. On one face is carved "An Official Order to the Command of the Five Thunders" [Chiling wu leihao ling 敕令五 雷號令], and on the side orders to the forces to be mobilized: “Tens of thousands of spirit generals, Thousands of troops and horses" [Wanwan shenjiang,

1 The final character was written this way, but probably should have been written 訣. The pages were torn and in poor condition at the top, so it is possible another character preceded the character 八. Eight Effective Formulas [Ba qinkoujue 八親口決] is a work of fifty-three pages that I bought in Beijing in January 2015. It is $9^{3 / 4}$ in $(24.76 \mathrm{~cm}) \times 6 \frac{1}{4}$ in $(15.87 \mathrm{~cm}) \mathrm{w}$. Drawings of some sha forces are on pp. 47-52 with pp. 43-46 showing talismanic characters dealing with sha. For a detailed review of the spirit generals see Nikaidō Yoshihiro 二階堂善弘, Yuanshuaishen yanjiu 元帥神研究 [Research on Marshal Gods], trans. Liu Xiongfeng 劉雄 峰 (Ji'nan: Qilu shushe, 2014).

(C) RONALD SULESKI, 2018 | DOI:10.1163/9789004361034_011

This is an open access chapter distributed under the terms of the prevailing CC-BY-NC License at the time of publication. 
qianqian bingma 萬萬神將, 千千兵馬]. ${ }^{2}$ On the opposite face is carved a likeness of the god of thunder showing him dressed in armor, brandishing a sword above his head with his right hand and riding on fire wheels [huolun 火輪]. In this depiction, he does not have the bird's beak with which he is often drawn. ${ }^{3}$

A portion of an incantation to these forces in the text Eight Effective Formulas (p. 19) reads:

The spirit soldiers with horses, go under the bridge; soldiers without horses, march under the bridge. Soldiers who arrive at the altar, remove your armor. As horses arrive at the altar, take off their saddles. At this time your follower will burn incense to ask a thousand soldiers and tenthousand horses to attend the altar.

You ma shenbing, qiaoxia guo; wuma shenbing, qiaoxia xing. Bing daotanqian, xiexia jia. Ma dao tanqian, xiexia an. Jinshi, dizi fenxiang, qing qianbing wanma, fu tanting.

\section{有馬神兵, 橋下過; 無馬神兵, 橋下行。兵到壇前, 卸下甲。馬到壇 前, 卸下鞍。今時弟子焚香, 請千兵萬馬, 赴壇庭。4}

2 Concerning lingpai 令牌: The trigram for pure north [qian 乾] of three unbroken lines $三$ is carved on the top (signifying heaven), and the trigram of two broken lines over an unbroken line $\mathbf{z}$ [zhen 震] is carved on the earth-facing bottom; it signifies thunder. This item was once actually in ritual use because the sacred object to give it ritual life still rattles around inside. There is another date, partially obscured, written at the end of the text being discussed, which appears to be December 1915 .

3 A description of a lingpai by Asano Haruji 浅野春二 in The Encyclopedia of Taoism, ed. Pregadio, 1: 411-415. The Daoist rituals I have seen where the lingpai was frequently used by banging it down on the altar with each command issued have been conducted by members of the Zhengyi sect. These have been principally the chaodu 超度 [salvation ritual to help the souls of deceased proceed out of the netherworld and toward rebirth] ceremonies conducted at Baiyunguan in Shanghai, Qinxiyangdian in Shanghai, and Huode zhenjun miao 火德真君 廟 in Beijing between 2011 and 2014. In his book about a Daoist spiritual leader in the modern period, anthropologist Liu Xun 劉迅 mentions the Shanghai Baiyunguan at the turn of the twentieth century in Xun Liu, Daoist Modern: Innovation, Lay Practice, and the Community of Inner Alchemy in Republican Shanghai (Cambridge: Harvard University Asia Center, 2009), 49-51.

4 In addition to the spirit generals, soldiers, and horses, other spirits are invoked in this work. On the summoning of spirit soldiers among villagers in Taiwan today, see Lin, Materializing Magic Power, 40-44. Mobilizing the spirit soldiers is referred to in Mark R.E. Meulenbeld, Demonic Warfare: Daoism, Territorial Networks, and the History of a Ming Novel (Honolulu: University of Hawai'i Press, 2015), 115-117. 


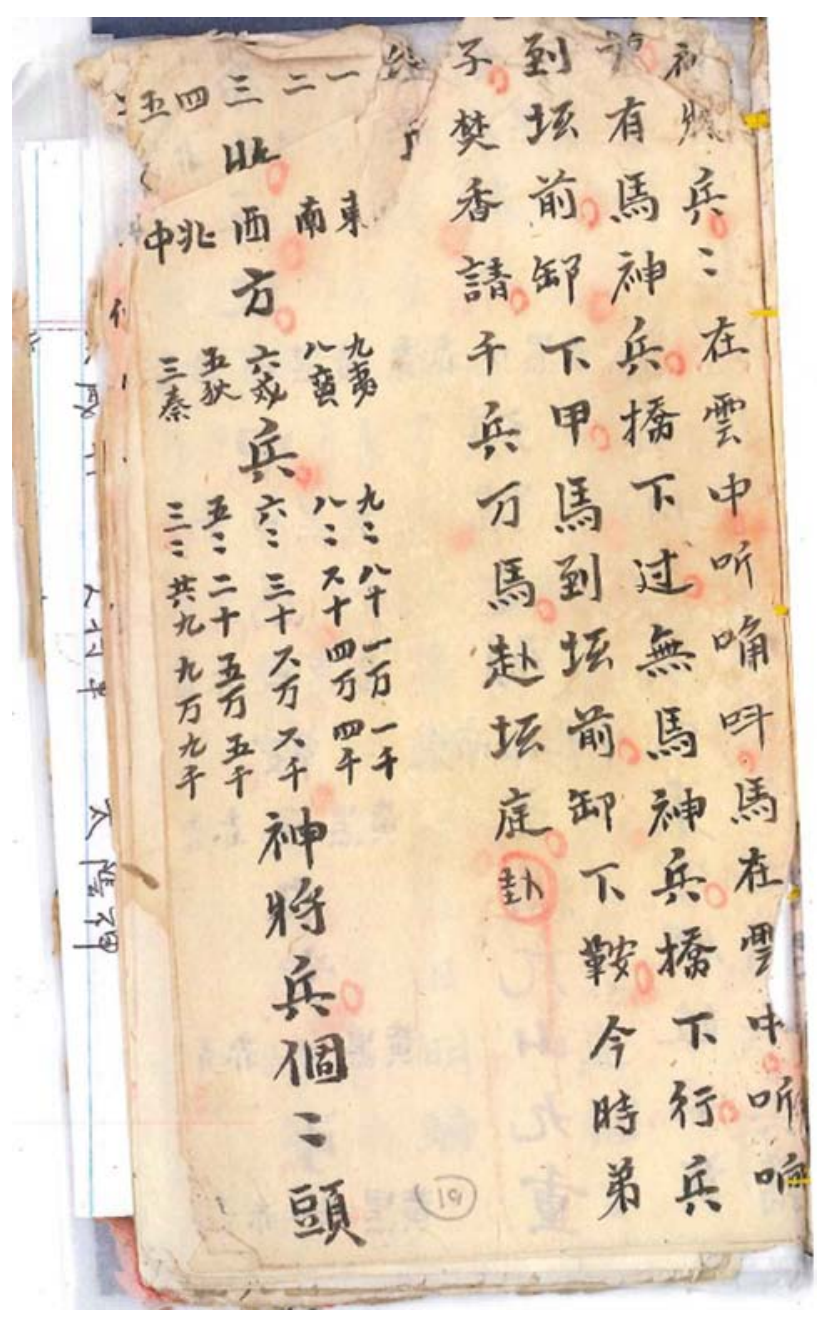

FIGURE 9.1

Eight Effective Formulas [Ba qinkoujue 八親口決], Page 19, Calling on Spirit Armies. The final character of the title, 決 jue, probably should have been written 訣 jue. This is a handwritten collection of incantations addressed to the Eight Evil Great Generals [Basha dajiangjun 八䰻大 將軍]. Because they are so powerful and frightening, the text also includes many magic talisman [fu 符] that can be used to command and control the generals. An example on page 19 reads (second vertical line from the right): "The spirit soldiers with horses, go under the bridge; soldiers without horses, march under the bridge. Soldiers who arrive at the altar, remove your armor. As horses arrive at the altar, take off their saddles. At this time your follower will burn incense to ask a thousand soldiers and ten thousand horses to attend the altar" [You ma shenbing, qiaoxia guo; wuma shenbing, qiaoxia xing. Bing daotanqian, xiexia jia. Ma dao tanqian, xiexia an. Jinshi dizi fenxiang, qing qianbing wanma, fu tanting. 有馬神兵, 橋下過; 無馬神兵, 橋下行。兵 到壇前, 卸下甲。馬到壇前, 卸下鞍。今時弟子焚香, 請千兵萬馬, 赴壇庭].

Pното BY AUTHOR 
Human ritual specialists on earth would hold a ceremony, as the ritual master is doing in this text, that often included writing a talisman [ fuzhou 符 咒] with magic writing and an incantation that instructed the spirit soldiers to come to the aid of a human being who was being troubled by demons or mischievous ghosts. Many of the handwritten materials with incantations to the spirits also give examples of efficacious talisman, as does this item. ${ }^{5}$

Where did all these ghosts come from? It was generally believed that anyone who had died a tragic or unexpected death was almost doomed to become a lonely, wandering ghost. People who died in war, with much loss of blood and disfiguration, were in that category. Their poor souls were angry that they had become hideous and frightful to others. So were those who died far from home amid uncaring strangers and would have no relatives to carry out the ancestor rites for them, no one to properly bury them and tend to their graves. Some people seemed mentally unstable from birth and incapable of participating in normal human society. All such wronged or traumatized or unstable people could become troublesome ghosts. Being lonely and disoriented, their spirits would wander around seeking to vent their anger and frustration on living people whose busy lives of worldly affairs left no time or inclination to sooth the turbulent spirits of a discarded soul.

Troublesome ghosts sometimes took possession of a place on earth. It could be a tree or a mountain pass. It could be a corner of the courtyard wall, perhaps near a well or near an outhouse. They might make strange sounds or take on a shape visible to living humans. They had the potential to cause people great harm, and the living were frightened by the presence of troublesome ghosts. These ghosts, it seemed, could be anywhere.

A huge collection of Daoist ritual manuals compiled in 1445, titled the Daofa huiyuan 道法會元 [Corpus of Daoist Ritual], contains a work called

5 The talisman in the chaoben discussed here are very serious and meant to summon the spirit generals and their troops. All talisman are meant to control ghosts, often by keeping them away. In many cases, they are for everyday protection and help, such as helping one obtain money or protect a child from illness. A collection of these protective talisman is illustrated and explained in Fengyunshanren 風雲山人, Guiling fuzhaojing 鬼靈符咒經 [Collection of Talisman for Ghosts and Spirits] (Taipei: Wuling chuban youxian gongsi, 2006). Drawings of various ghosts to be petitioned and controlled by Daoist priests are in the chaoben in my collection titled We Petition [ fuyi 伏以]. This work has no cover or title, so I assigned this title based on the first characters on the first page of the text. The book is 11 in $(27.94 \mathrm{~cm}) \mathrm{h} \times 7^{1 / 2}$ in $(19.05 \mathrm{~cm})$ w, with sixty-six pages. I bought it in Beijing in January 2015. Drawings of these ghosts are on pp. 37-48. A book of this large size would be good when used for instructional purposes. 
“Yuchen jingfa liandu neizhi bingxu 玉宸經法錬度內旨并序 [Preface on Secret Instructions for the Sublimation Ritual in the Sutra of the Jade Palace]." A portion of this preface, expertly translated by Mark R.E. Meulenbeld, describes how some unfortunate souls become troublesome ghosts.

They naturally follow the breaths ( $q i$ 岳) of dark turbidity and submerge beneath the earth; then they become devils and demons. Others base themselves in the grasses or take possession of trees, and they practice pestilence and bewitchment. Some are born into the world and become stupid and lewd people, with bodies and faces that are imperfect. Others are born among the barbarians, or transformed into abnormal species. Some essential spirits float around, with their cloud-souls (hun 魂) and bone-souls ( $p o$ 魄) still congealed they are unaware that their body and bones have decayed; they cling to the desire of eating boys and girls in this world. They have thoughts of taking revenge on their relatives. They are as if drunk without ever sobering up, they are as in a dream from which they will not awake.

Ziran suihun zhuozhiqi, chenlun dixia, zeweili weigui. Huо yicaofumu erweili weiyao. Huo shengyushi, zewei yuwan xiajian, tixiang bujuzhi ren. Huo shengzaibianyi, huo huaweiyilei. Huozhe jingshuang piaochen, hunpo jiezhi, buzhi xingti yihuai er youzhi zaishi yinshi nannv zhiyu. Yuanqin baofu zhinian. Ruzuifuxing, ru meng fujue.

\section{自然隨昏濁之息, 沉淪地下, 則為厲為鬼。或依草附木而為庽為妖。 或生於世, 則為愚頑下賤, 體相不具之人。或生在邊夷, 或化為異 類。或者精爽漂沉, 魂魄結滯, 不知形體已壞而猶執在世飲食男女之 欲。冤親報復之念。如醉弗醒, 如夢弗覺。6}

For the typical Chinese peasant family living and working in a rural village or in the countryside, troublesome ghosts or goblins could appear unexpectedly

6 Meulenbeld, Demonic Warfare; English text, 156-157; Chinese text, 232. Hun and po refer to the two aspects of the soul. Hun is the spirit of the soul, and po refers to the corporeal body of bones and flesh that also has a soul. The two types of souls are explained in Chapter 8 . This passage speaks of a desire to "eat and drink boys and girls." This is the literal translation of the text, which could in fact refer to the desire of ghosts to eat people. It could also refer to the desire to have sexual relations with people. Chinese ghost stories tell of both events taking place. In contemporary Chinese slang, to want to "eat" [chi 吃] someone expresses the wish to have sex with that person. 
at any time. Their mischief included causing accidents, making things spill or break, or introducing any misfortune that interfered with the peasant's daily work and life. In the popular imagination, these ghosts were usually tiny or miniature creatures, able to jump and hide and disappear. They could be green or have a bright red face. Sometimes they were bobble headed or repeated some action over and over. Some were evil and frightening, and others were deceptively not unpleasant, even though they brought annoyance and trouble. Some took the initial form of a charming young girl or a Buddhist monk, though they might then change into another creature or disappear into thin air. Often these goblins affected the physical and mental health of the peasant, which, as we see below, was one way to detect their presence. ${ }^{7}$

Troublesome ghosts could be dealt with by ritual specialists in simpler ways than by holding a Daoist religious ceremony. Sometimes a local Daoist priest knew the procedures for chasing away a ghost. Some communities had a yinyang master, who had studied about ghosts and how to remove them. Yinyang specialists had studied all the calculations involved in the ritual calendar, the stars, and their influences, which they combined with other phenomena as the calendrical cycle proceeded. He could select a propitious day for a marriage, for moving house, or for a funeral. He could help determine the optimal location for the front gate of a house to receive the blessings of the symbolic universe through geomancy [fengshui 風水]. Similarly, he could select the most auspicious spot for a grave in order to ensure continued blessings on the family by the spirit of the departed.

7 Many descriptions of troublesome ghosts and goblins are given in G. Willoughby-Meade, Chinese Ghouls and Goblins (New York: Frederick A. Stokes, 1926 [?]); illustrations of some of these creatures are on pp. 26, 37, 139, 179, 293, and 294, and a drawing of the Oxhead Spirit General Zhao Ziyu [Dingchou shenjiang ming Zhao Ziyu 丁丑神將名趙子玉] is on p. 74. Before the book's publication in 1926, the nearest dingchou 丁丑 year would have been 1877 , which could be a likely date for this drawing. Ghosts and demons are discussed at length in Plopper, Chinese Religion Seen through the Proverb, 77-117, with an illustration of one of these ghosts on p. 117. The belief in strangely formed goblins has a long history in China. Many of these fantastic and often threatening creatures are described in the ancient work the Shanhaijing 山海經 [Classic of the Mountains and Rivers], apparently already known in China in the third century вСЕ. A study discussing these creatures, with many illustrations is Itō Seiji 伊藤清司, Chūgoku no shinjū, akki tachi: Sankaikyō no sekai 中國の神獸, 惡鬼たち：山 海經の世界 [Chinese Spirit Beasts and Bad Ghosts: The World of the Classic of Mountains and Seas] (Tokyo: Tōhō shoten, 2013). Professor Itō's 1986 edition was expanded by scholars of the Kodai Chūgoku kenkyūkai 古代中國研究會 [Ancient China Research Seminar] at Keio University. 


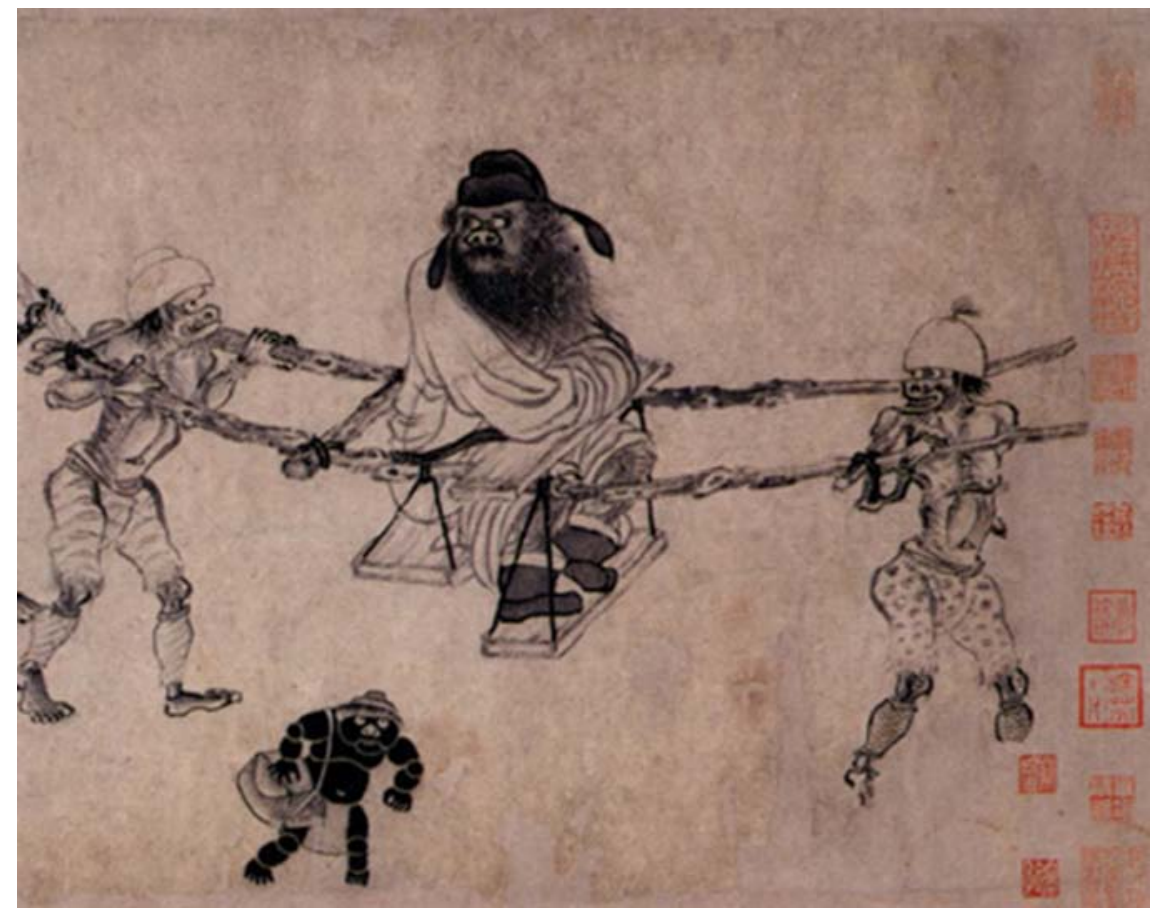

FIGURE 9.2

Zhong Kui and Ghosts [Zhong kui 鐘道]. This deity is able to tame wild ghosts and demons. Here he has them willingly do his bidding.

FROM THE PAINTING GONG KAI, ZHONG KUI TRAVELING (C. 1304), FREER GALLERY OF ART, WASHINGTON, D.C.

When the yinyang master confronted a ghost, he could use proven ritual objects, such as a sword made of peach wood, a willow branch, or a brass bell. Poor peasants who were besieged by a troublesome ghost but had no ritual master nearby or perhaps not enough money to pay for his services, had fairly simple ways of getting rid of unwanted ghosts. The afflicted person could throw a slipper at it or hold up a mirror that would reveal its true shape as a demon, which would become frightened. One could throw firecrackers at it to make the frightened ghost run away. If the ghost was hiding in a crack in the wall, the crack could be pasted over with paper or with mud, and the ghost would be trapped. If one was able to identify the name of the ghost and to call it out, the ghost would become frightened, because it had been discovered and identified, and it would hurry away. Calling out a goblin's name was considered an effective way of weakening its resolve and making it leave. ${ }^{8}$

8 Some of these techniques are mentioned in Kohn, Introducing Daoism, 77. Several often used techniques are given in Plopper, Chinese Religion Seen through the Proverb, 133-136. 


\section{Fifty Days to Encounter the Five Spirits}

One chaoben is titled Fifty Days to Encounter the Five Spirits [Wushi zhirifeng wudao 五十之日逢五道]. The book's title refers to the "five robbers" [wudao 五 道], but on page 18 it mentions the "five spirits" [wudaoshen 五道神]. ${ }^{9}$ Who were the five spirits?

According to the Zhongguo shenguai dacidian 中國神怪大辭典 [Dictionary of Chinese Gods and Spirits], the five spirits were a band of robbers in Central China in the mid-fifth century, a time when several local kingdoms were competing against one another. The five robbers—Du Ping 杜平, Li Si 李思, Ren An 任安, Sun Li 孫立, and Geng Yanzheng 耿彥正 ${ }^{10}$ — created disturbances in order to rob and pillage. After they killed a Chinese general from the kingdom of Liu Song 劉宋 (in roughly 469), they became well known for their prowess, and people in the area began to honor them as spirit generals. It was a time when people of all social classes held an active belief in ghosts and spirits. Although the five robbers were honored for their feats, they were seen as local evil gods [xiong shen 兇神]. They are identified among the troublesome ghosts in some cases by the yinyang master. The people originally referred to them as the "five robbers" [wudao 五盗]. Over the centuries, they became known as the "five spirits" [wudao shen 五道神].11

These five spirits do not appear on any of the organizational charts of Daoist deities, but they can be said to have existed in the minds of many of the

9 Fifty Days to Encounter the Five Spirits is a short text of nineteen pages. It is $7^{1 / 4}$ in $(18.41 \mathrm{~cm}) \mathrm{h} \times 5$ in $(12.7 \mathrm{~cm}) \mathrm{w}$, bound with twine. I bought it in Beijing in December 2012. An illustration of a Daoist talisman written to keep robbers away appears in Robert J. Antony, Unruly People: Crime, Community, and the State in Late Imperial South China, (Hong Kong: Hong Kong University Press, 2016), 87. Antony gives a detailed discussion of the pingmin he calls the "working poor" who turned to banditry and crime as a way to survive.

10 These are the names listed in a text probably dating to the late 150os, Sanjiao soushen daquan 三教搜神大全 [Great Compendium of the Unseen Spirits of the Three Teachings], in the version reprinted about 2004 and available at Baiyunguan in Beijing; see 2 ce 冊, 4 quan 券, pp. 4-5. This publication is mentioned in von Glahn, The Sinister Way, 217-218, bibliographic entry 328 .

11 Yi, Zhongguo shenguai dazidian, 554. The two entries I recommend as clues to the five spirits in question are the five robber generals [wudao jiangjun 五盗將軍] and the generals of the five Dao [wudao jiangjun 五道將軍]. There also exist gods of wealth of the five roads [wulu caishen 五路財神], on which, see Philip Clart, in The Encyclopedia of Taoism, 1: 243 . 
common people of China who were influenced by Daoist thinking. ${ }^{12}$ The five spirits are among the rabble of ghosts and demons who populate the lower strata of the world of spirits. They could be among the goblins who interact to cause human beings harm, as do all the troublesome ghosts. When maladies, misfortune, ill health, or other difficulties arise in the course of a person's life, troublesome ghosts are likely to be found as the cause.

When someone is annoyed by a ghost, the first course of action was to consult the booklet by the yinyang master discussed here or to consult with the master himself, to identify and locate the offending ghost. The yinyang master may have kept this book for his own reference when his help was requested. Often the ghost or ghosts can be made to leave by performing some simple actions, as outlined above. In more severe cases, in which the ghost refuses to depart or the afflicted person feels especially burdened, the troublesome ghosts can be forced out by invoking the spirit generals to mobilize their yin soldiers against them. Accompanying this operation was the writing of talisman, often in red ink on yellow paper, to order the spirit generals into action with their troops. The talisman was also being pasted on the gate or the house or in a room or even worn by the afflicted person. ${ }^{13}$

12 The complete intertwining of commonly held beliefs from popular religion that form the worldview of many rural Chinese communities even in the present is explicated in Tiksang Liu, "A Nameless but Active Religion: An Anthropologist's View of Local Religion in Hong Kong and Macau," China Quarterly, no. 174 (2003): 373-394. See also Liu Tik-sang liu 劉迪生, “'Difang zongjiao' yu 'minsu chuantong': Xianggang tianhou chongbai huodong de bianqian 地方宗教與民俗傳通 : 香港天后崇拜活動的變遷 ['Local Religion' and 'Popular Traditions': Changes in the Worship of Mazu in Hong Kong]," Mazu yanjiu xuebao 媽祖研究學報 [Journal of Mazu Research], 1 (2004): 48-57.

13 Spirit generals could be summoned to mobilize their troops in many ways, as seen in Zhang and Wu, Daojiao Fuzhou xuanjiang. A fictionalized account of a professional yinyang master in recent times but still using traditional techniques, is given by Zangfeng yunqi 藏風運氣, Yinyangshi riji 陰陽師日記 [Diary of a Yinyang Master] (Guangzhou: Xinshiji chubanshe, 2011). A prolific Japanese fiction writer whose pen name is Yumemakura Baku (which means Pillow of Dreams Tapir) has been publishing works on ghosts and disembodied spirits for over the past twenty-five years, including accounts of a yinyang master. However, the stories in his books are in the vein of Japanese ghost stories and strange encounters with disembodied spirits and portray situations somewhat different from those discussed here. For example, they have a more literary and Buddhist religious frame. An example of this genre is Yumemakura Baku 夢枕獏, Onmyōji: sōkō no maki 恩 陰陽師：蒼猴の巻 [Yinyang Master: Blue Monkey Collection] (Tokyo: Bungei shunjū, 2014). Another chaoben in my collection I have titled Cao Suosen 曹鎖森, from the name written on the cover. I bought this handwritten book of seventy-seven pages in Shanghai 
The yinyang master who compiled this book indicated that, in any fifty-day period, people might encounter troublesome ghosts, as epitomized by the five robbers. His purpose was to help those afflicted with a troublesome ghost to identify the spirit and to cause it to leave. He used a fifty-day period as the time frame for his text and listed each day according to its designation in the traditional Chinese calendrical cycle.

\section{Calculating the Days}

According to archaeological finds, for about three thousand years, the Chinese have been keeping track of time using a system of ten heavenly stems [tiangan 天干] and twelve earthly branches [dizhi 地支]. Although China has used numerous systems for counting time and making calendars over its long history, the stem-branch [ganzhi 干支] binary system in its various permutations has been one of the longest in use. One stem and one branch make up a pair. Each pair stands for a unit of time. This can be illustrated by listing the ten branches and twelve stems to show how they combine.

Ten heavenly branches:

$$
j i a \text { 甲 } y i \text { 乙 bing 丙 } d i n g 丁 w u \text { 戊 } j i \text { 己 geng 庚 xin 辛 ren 王 } g u i \text { 癸 }
$$

Twelve earthly stems:

$z i$ 子 $c h o u$ 丑 yin 寅 $m a o$ 卯 $c h e n$ 辰 $s i$ 巳 $w u$ 午 $w e i$ 未 shen 申 $y o u$ 西 $x u$ 戌hai 亥

in December 2014. It is $8 \% 4$ in $(22.22 \mathrm{~cm}) \mathrm{h} \times 5$ in $(12.7 \mathrm{~cm}) \mathrm{w}$, written on badly deteriorated handmade paper. In quite passable calligraphy, it offers incantations to deal with many illnesses, often with an example of an efficacious talisman character. These were the magic characters that could be pasted on a doorway or above a bed or worn by the afflicted person or dissolved in tea and drunk. It refers to the Celestial Lord Who Relieves Suffering [Taiyi jiuku tianzun 太乙救苦天尊] on p. 11. This deity, discussed in Chapter 8, is usually associated with death, because he descends to Hell to search for and free tortured souls. Most of the medical issues addressed in this work, however, seem to deal with physical complaints, rather than with death. This means the text was used by people with various maladies; it was not compiled for funerals. 


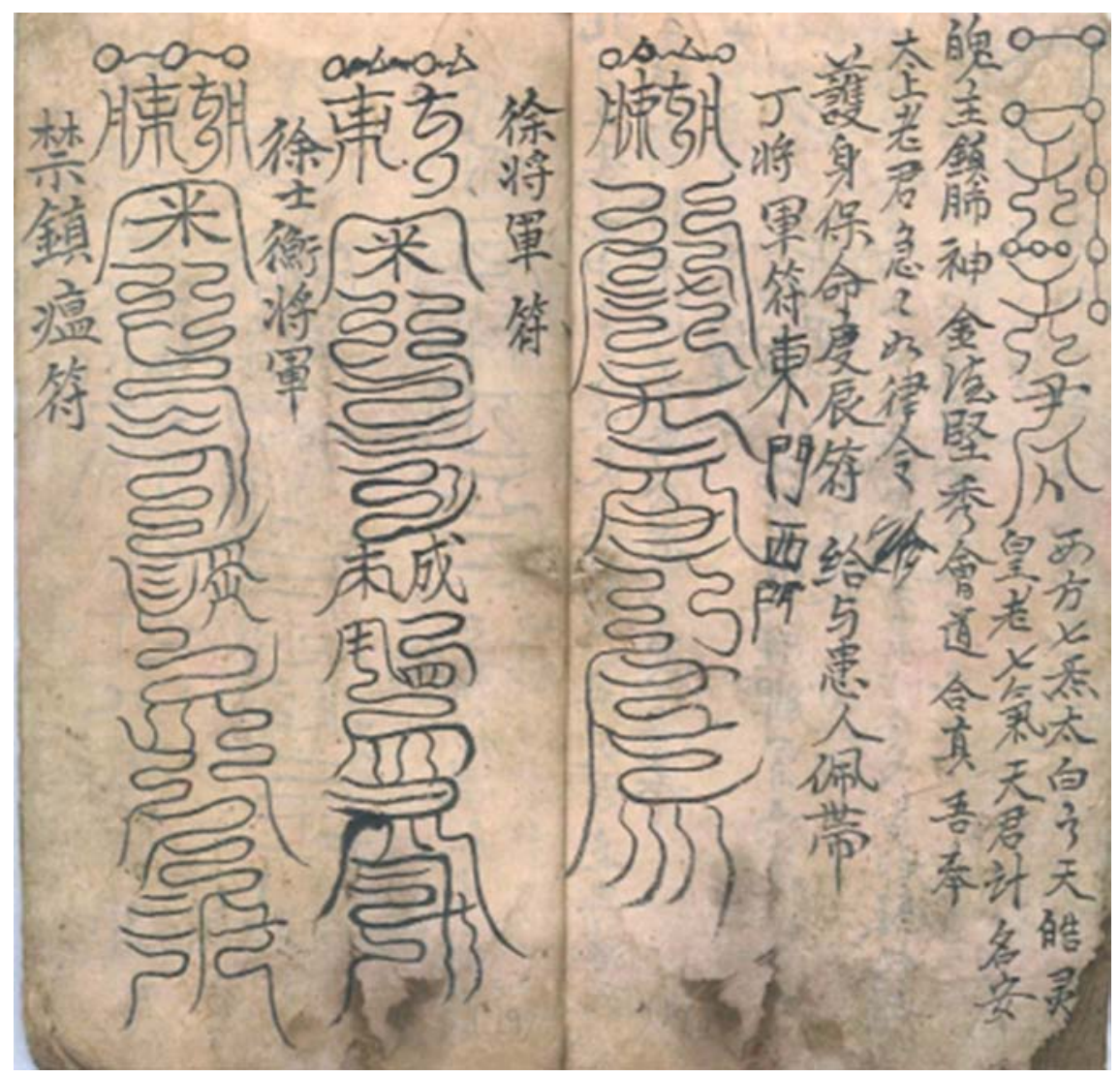

FIGURE 9.3

Cao Suosen 曹鎖森, Pages 18 and 19, Call the Spirit Generals. Cao Suosen is the name of the person written on the cover, so I use it as the title of this chaoben. The booklet is a list of incantations to deal with illnesses and other human afflictions, many of which are accompanied by a talisman character that will mobilize the deities to help the afflicted. Page 18 shows the fu for summoning General Ding [Ding jiangjun 丁將軍], and page 19 gives two talisman for summoning General Xu [Xu jiangjun 徐將軍]. Both are powerful spirit generals [shenjiang 神將], who command thousands of spirit soldiers [shenbing 神兵]. The final line on page 19 (far left-hand side of the page) indicates that the following page has a talisman for “preventing plague" [jinzhenwen fu 禁鎮瘟符].

Рното ву AUTHOR

The combination of one from each line is most commonly seen when it is used as a designation for years. The first branch jia 甲 will be combined with the first stem $z i$ 子 to designate a year known as a jiazi 甲子 year. The two most recent jiazi years were 1924 and 1984. If 1924 was a jiazi year, then to designate the following year, 1925, we take the following letter from the branches yi 已, and the following letter from the stems chou \#, to get the yichou 已丑 year. We make this combination in turn for each branch and stem. 
If we continue on from 1925, when we complete ten combinations [guiyou 癸西, 1933], we will have completed the line of branches, but two terms remain in the stem line. So we go back to the start of the branch line jia 甲 and combine it with the eleventh remaining stem $x u$ 戌, and we come up the jiaxu 甲戌 year (1934). We take the second branch term yi 乙 and combine it with the twelfth remaining branch term hai 亥 to get the yihai 乙亥 year (1935). We thus create a twelve-year cycle, based on the ten branches.

What becomes clear as we go through this orderly process of combining the branches and stems is that they will not exactly correspond as they did in the first run through because the branches are ten and the stems are twelve. However, when we follow the combinations through six cycles (six times) of the branch line, the first terms in both the branch and stem lines once again align. Thus by this calculation every sixty years we complete a cycle of all the possible combinations of these terms. In this case, the final terms in both the branches and the stems align, to form a guihai 癸亥 year (1983). This sixtieth year is celebrated in East Asia as huanli (in Chinese) or kanreki (in Japanese) 還暦, meaning the cycle has been completed, and the calendar has been restored to its original position, so the sixtieth birthday is treated as a special celebration. ${ }^{14}$

14 A through explanation of this system in English is in Endymion Wilkinson, Chinese History: A New Manual (Cambridge, MA: Harvard University Asia Center for the HarvardYenching Institute, 2013), 532-543; and in "Chinese Astrology," http://en.wikipedia.org/ wiki/Chinese_astrology/, accessed September 18, 2014. For a clear explanation in Japanese, see the Japanese Wikipedia site: http://ja.wikipedia.org/wiki/\%E5\%B9\%B2\%E6\%94\% $\mathrm{AF} /$, accessed September 19, 2014. The chaoben in my collection discussed in Chapter 8, Secret Text for Summoning the Snake [shechuan miben 蛇傳秘本], has a handwritten chart on p. 28 of the heavenly branches and earthly stems that shows how to combine them in order to move through the cycle, organized according to the jia designation. This illustrates that the ritual master who wrote the text was using calculations according to this system. Another chart useful for making the calculations is in Min, Shinsalhak chonso, 33. The heavenly branches and earthly stems system is outlined and elaborated on to show how to use the system for fortunetelling in Wang Sisi 王思思 and Wang Desen 王德森, ed., Xiuzhen nianliyuzhisuanfa 袖珍年曆與指算法 [Pocket Calendrical Calculations and Using the Fingers for Calculations] (Shanghai: Shanghai kexue zhishu chubanshe, 2011), 1-51. A thorough and chronological explanation of Chinese astrological and calendrical thinking, an original form of rational and scientific thought according to the author, is Yabuuchi, Chügoku no tenmon rekihō. The manner in which the twelve earthly branches were appropriated in popular folklore to make up the animal signs of the zodiac is covered in Ishigami Nanasaya 石上七鞘, Jūnishino minzoku denshō十二支の民俗伝承 [Popular Lore about the Twelve Branches] (Tokyo: Ōfū, 2003). For an alternate method of 
This system can be used to designate any period of time. It is most common to designate years, but it can be used for months, weeks, days, or hours. By then linking the various stem and branch combinations to seasons, colors, elements, and, especially, star deities, a holistic web of positive and negative forces can be created to distinguish lucky [ $j i$ 吉] and unlucky [xiong 兇] time periods. Fortunetellers use these combinations to advise which days are propitious and times for actions, such as when to get married, hold a funeral, invest in a business, or begin a long journey. The text we discuss here is organized according to this system. ${ }^{15}$

The book Fifty Days to Encounter the Five Spirits originally listed fifty days, each day designated by its stem and branch combination. We know that, because forty-six days are listed, the first four days were lost when the title page and the page with the first four days were detached from the book. We also know that, by taking the designations we do have and working backward according to the progression of stems and branches, we can determine which days were lost. The first four days in this fifty-day cycle that were lost were for the jiaxu 甲戌, yihai 乙亥, bingzi 丙子 and dingchou 丁丑 days. But according to the next days in the cycle, beginning with the wuyin 戊寅 day, the remaining forty-six days are complete in the text.

In fact, a fragment of the lost dingchou day tells us that the troublesome spirit for that day hides in the well of the oil lamp in the northwest direction of the house and should be driven out to result in great happiness [Zaixibei, youdeng youpingnei cangzhi, chuzhi liji 在西北油燈油瓶內藏之, 出之利吉].

We can now begin to follow each of the remaining forty-six days listed in this book. The text is translated in full in Appendix D and is shown in its original text in Figures. 9.4 and 9.5.

using calendrical calculations to reveal human virtues, see He Wumeng 何無夢, Shunshou qizheng: Chuantong Zhongguo shehui de qiuren moxing 順受其正：傳通中國社會的 求仁模型 [Willingly Submit: A Model for Seeking Humaneness in Traditional Chinese Society] (Shanghai: Huadong shifan daxue chubanshe, 2016). The phrase translated here as "willingly submit" [shunshou qizheng 順受其正] is taken from a phrase in Mencius (book VII, part 1, Jinxin 盡心, chapter 11). Mencius was discussing the "Will of Heaven" [tianming 天命] and its infallibility, and he suggested that humans willingly submit to this force.

15 This is the basic system for most horoscopes and almanacs published in China. For example, see the widely used Zhongbaolou tongsheng 眾寶樓通勝 [Treasure House for the People] (Jiangmen: Guangdongsheng jiangmen tuchan jinchukou youxian gongsi, 2014); and Erlingyiwu yiweinian tongli 2015 乙未年通暦 [Horoscope for 2015] (Hong Kong: Haifeng chubanshe, 2015). 


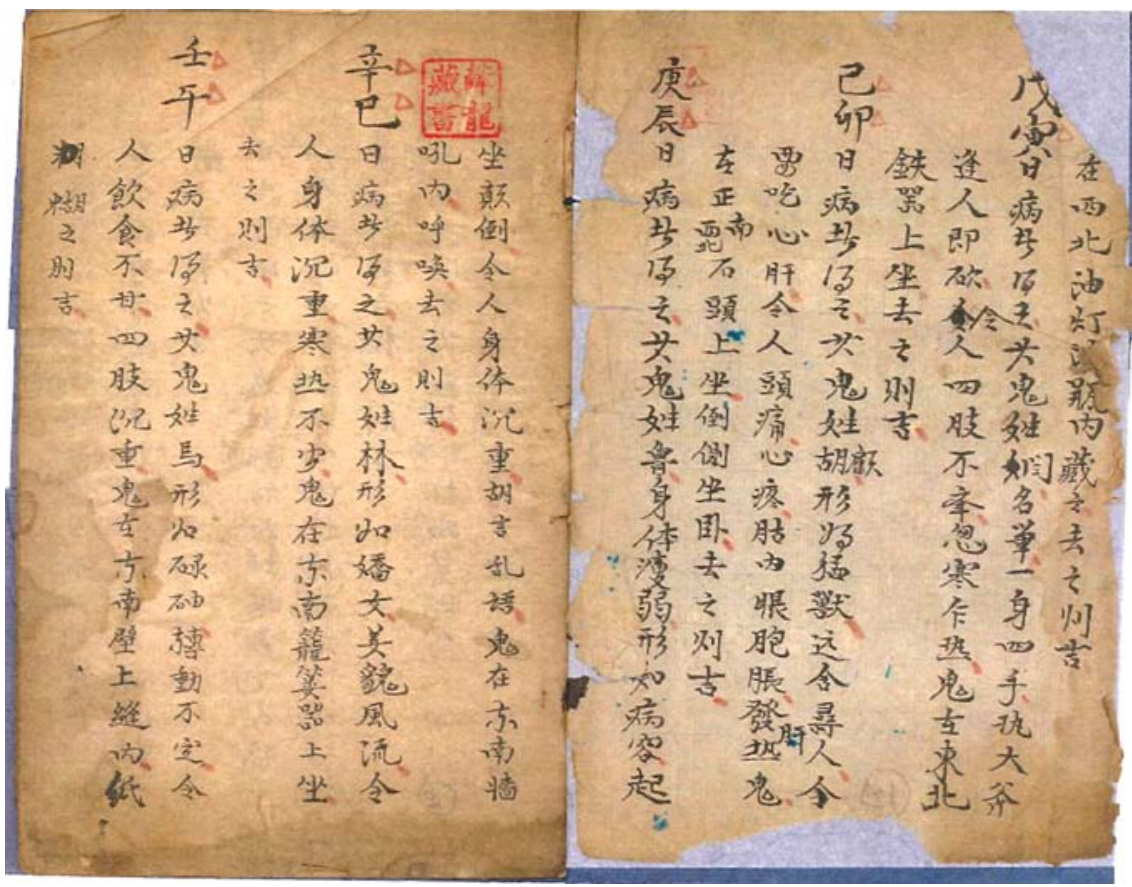

FIGURE 9.4

Fifty Days to Encounter the Five Spirits [Wushi zhiri feng wudao 五十之日逢五道], Pages 1 and 2, Detail of a Day's Evil. This is an example of written material that might be used by a yinyang master [yinyangshi 陰陽師] or an exorcist. It contains a list of a sixty-day cycle (in this item, a fiftyday cycle) describing the goblin that might cause physical distress on each particular day. Page 1 begins by describing a wuyin 戊寅 day: “For those afflicted on this day, the ghost is surnamed Yan 閆, named Zhao 嵂. It has one body with four arms, holding a large ax. When it encounters humans, it begins chopping. It causes people to be unable to raise their four limbs and to feel cold and then suddenly hot. This ghost is settling in the northeastern direction on something metal. It would be good for it to depart" [Wuyinri bingzhedezhi, qi gui xing Yan, ming Zhao. Yi shen si shou zhidafu. Fengren jikan. Lingren sizhi buju, huhanzhare. Gui zai dongbei tieqi shang zuo. Quzhi zeji 戊寅 日病者得之, 其鬼姓閆名娆。一身四手執大斧。逢人即砍。令人四肢不舉, 忽寒乍 熱。鬼在東北鐵器上坐。去之則吉].

Pното BY AUTHOR

All the items and places within the home mentioned in these descriptions would have been in a typical home in premodern China. They might have equally been in an urban or rural home, though they seem more likely to have come from a rural home, filled with straw baskets, pegs in the walls for hanging things, and pots and pans for cooking or transporting grains and oil. Another reason for assuming a rural household is that these afflictions are more likely to be confronted by a person living in a rural area. In that environment, where practices of good hygiene and sanitation were not carefully followed, perhaps 


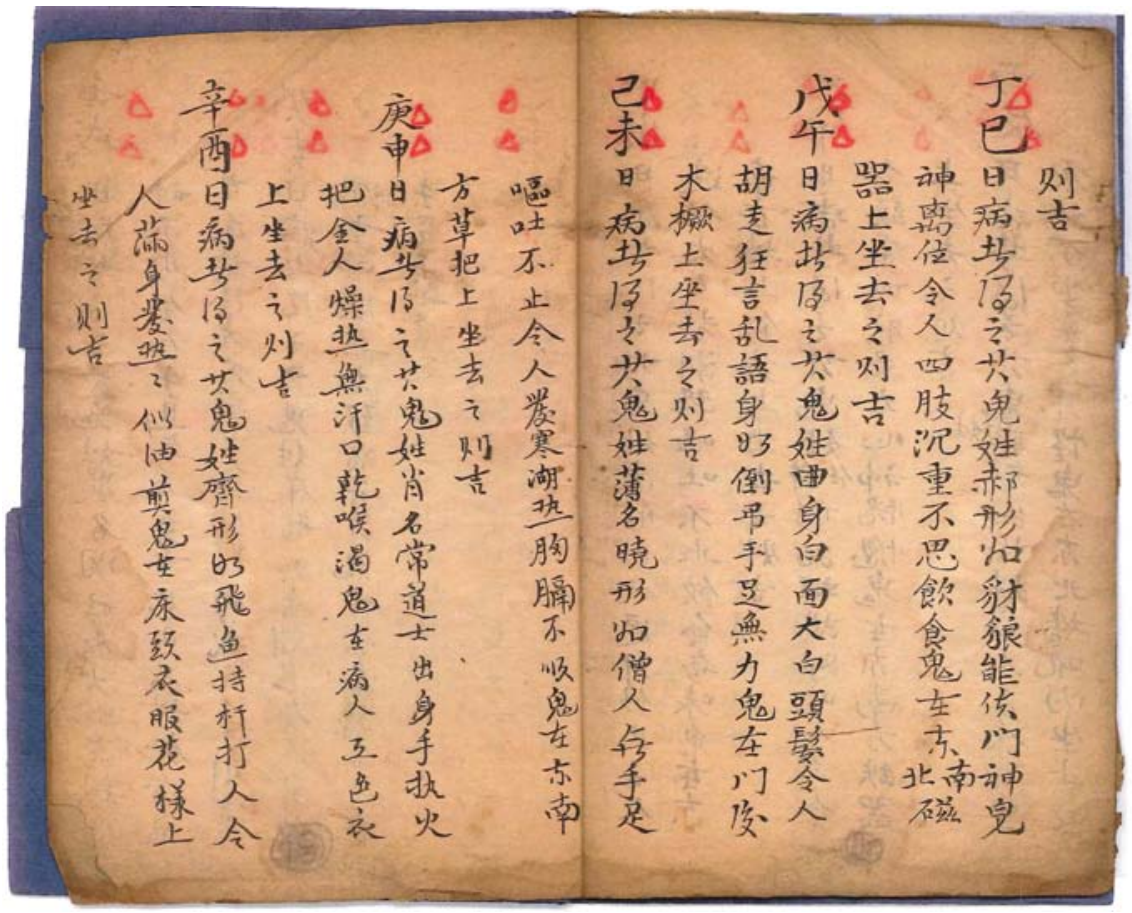

FIGURE 9.5

Fifty Days to Encounter the Five Spirits [Wushi zhiri feng wudao 五十之日逢五道], Pages 15 and 16, This Evil Frightens the Home's Protective Gods. On the right-hand side, page 15 begins with the dingsi 丁巳 day: "The person afflicted on this day is bothered by a ghost surnamed Hao 郝. It is shaped like ajackal/wolf that can make the door gods and the kitchen god leave their posts. It causes the four limbs to feel heavy and makes a person lose his appetite. The ghost is found in the southeast or northeast, sitting on a pottery vessel. It would be good for it to depart" [Dingsiri bingzhedezhi, qigui xingHao. Xing ru chailang, nenggong menshen zaoshen liwei. Lingren sizhi chenzhong, busi yinshi. Gui zai dongnan, bei, ciqishangzuo. Quzhi zeji丁巳日病者得之, 其鬼姓郝。形 如娐狼能供門神㿝神離位。令人四肢沉重, 不思飲食。鬼在東南, 北, 磁器上坐。 去之則吉]. The door gods and the kitchen god protect the house and the family that lives in it. This evil spirit is so frightening that even these protective deities run away.

Pното BY AUTHOR

not even known by the majority of people, the resulting medical complaints would be of the type mentioned in these descriptions of ghostly maliciousness. For example, for rural people working in dirty water and around animal waste, problems of the digestive tract, skin ailments, loss of appetite, and listlessness and fatigue were not uncommon. ${ }^{16}$

16 A British medical doctor working in Hengyang 衡陽 and Tianjin from 1899 to 1922 has chronicled many of these medical complaints. See Peake in China. 
I asked a friend living and working in Boston, a knowledgeable Chinese doctor trained in both Asian and Western medicine, to comment on this handwritten text from a medical standpoint. He is Dr. Wong Ming (Huang Ming 黄明). I offer here a paraphrase and summary of his comments. ${ }^{17}$

From the traditional Asian medical point of view, the forces of yin and yang need to be maintained in a balance for healthy living. The negative effects of yin can include chills, weakness, lethargy. The negative effects of yang can include a burning in internal organs, a strong headache, sweating and nervousness. Most of the symptoms exhibited by the afflicted persons described in the text represent an upset to that balance as expressed by their symptoms, from feelings of lethargy to mental confusion to vomiting.

In the general Western medical approach, there is an underlying philosophy of rationalism, to study the various parts of the body, to determine how they should behave, and the purpose of their functions. This is all based on the physical, on what can be seen and studied through repetitive experiments. On the other hand, in the Asian system there is a very broad view of the context in which all life exists in relation to all of the forces that are in play. All the physical symptoms observed should be considered in relation to the larger perspective. They should be explained and dealt with in that context. This is a very broad conceptualization. Anthropologically speaking, the Chinese medical specialists were following a reasonable nonrationalism to fit their observations into the larger theory.

Some Chinese medical people felt that Westerners had a high degree of yang influence, while Chinese had a higher degree of yin influence. This impacted their perceptions of how to approach medical conditions caused by an imbalance of the two forces. This can be called a theory of the non-equilibrium of thermodynamics. It is a kind of physics approach, but one that should be called quasi-physics, because at the level of folk culture it allowed for the entry of ghosts or goblins as causative agents.

In the school of yin-yang thought, the yinyang master had a wisdom system that postulated a high degree of free energy, and their view of

17 Dr. Wong has published his method of medical analysis in Huang Mingda 黃明達, Zhongyixue hexingershangxue:Boshitun de suixiang 中醫學和形而上學: 波士顿的隨 想 [Chinese Medicine and Metaphysics: Boston Ruminations] (Shanghai: Shanghai renmin chubanshe, 2008). An English-language version was published as Ming Wong, Traditional Chinese Medicine (тсм) and Metaphysics (Baltimore: Publish America, 2010). His advice on an herbal recipe for a sleep aid was given to me as recorded in Chapter 4. 
the interplay of these forces was not discrete, but was instead very wideranging. This allowed them to deal with ghosts and goblins without feeling guilty toward the people they were trying to help. In fact, by offering a placebo or type of hypnosis, their patients could actually feel better after the treatment was delivered. It also allowed for both physical and mental problems to be addressed.

Take the situation of the Wuyin Day 戊寅 described above. In this case the ghost had one body with four arms, holding a large ax; when it encounters humans it begins chopping. It caused people to be unable to raise their four limbs, to feel cold and suddenly hot. By Asian theory, the patient was suffering from weak yin and yang inside the body. Medically the person caught a "wind," and the body experienced hot and cold. In Western medicine this would be similar to a malaise, low fever, perhaps a viral infection. By pinpointing the ghost, and then causing it to leave, the balance of yin and yang could be restored. The ghost was a type of placebo, and getting rid of it allowed a degree of recovery.

In the case of the Yimao 乙卯 Day, the ghost was like a wild beast searching for someone and acted like it wanted to eat their heart and liver. It caused the afflicted to get a headache and fever, the eyelids to swell and the stomach to become hot. This was a more serious case than the one in the preceding paragraph. This patient also had low yin but with high yang. $\mathrm{He} /$ she caught a "fire" from outside, his/her liver was affected which also affected the stomach. The ghost caused the bad situation, so the ghost had to be removed. Possibly in this case seeing the ghost as a placebo and removing it by itself it would probably not relieve the medical condition. This might have been a case of gastritis.

Finally, let's look at the case of the Gengchen 庚辰 Day. The ghost was thin and frail, it gets up and falls down headfirst. The person's body feels heavy, the patient speaks strangely in nonsense syllables. The medical symptoms seem to be lethargy and confused speech. This person also caught a "wetness" from the outside, affecting the kidney, and a "dampness" in the heart affecting his/her mental condition. From the Western perspective, the person needs psychological consultation, help with stress management, and medication to treat depression and anxiety, possibly a life-style adjustment. Here again, as in the case of the Wuyin Day, removing the placebo (the ghost) or a form of hypnosis (perhaps through a ceremony of chasing off the ghost) would probably not relieve the situation in any long-term sense.

When the medical situation was not too serious, it could be relieved by yelling at the ghost to leave, or by calling on the spirit generals or writing 
a talisman to keep the ghost away. We should keep in mind that not all Chinese people subscribed to this behavior. It was popular among the common people as part of the "folk culture." This is a medical tradition that has been largely ignored and not studied much. It seems to me that because philosophically China had a lot of theoretical interconnections involving the number five, such as five colors, five elements, five directions, etc., to turn the number five into five ghosts or spirits, as in the "five spirits" discussed above, we see a logical outcome from more sophisticated thinking, down to the level of popular folk beliefs.

Another aspect of understanding the medical conditions described in this chaoben is seeing them as a catalogue of afflictions that were probably typical among the poor workers and peasants in rural China. They could grow exhausted from hard work and feel unable even to move their limbs. They could get bad headaches from their weakened physical condition or from the stresses of surviving in an environment that presented many difficulties. Suffering from a severe infection or bodily malfunction, they could get chills, pains, or vomiting. A combination of factors could also lead to erratic and worrisome behavior, such as falling down or speaking unintelligibly.

In the description of each of the ghosts above, could it be said that, psychologically speaking, the ghosts represented the anxieties and fears of the afflicted? For example, a ghost that chops away at someone represents the dangers of a perceived hostile environment; a ghost that bobs its head unable to control it movements or otherwise to be effective in its environment expressed the confusions of a person who felt useless and marginalized; a ghost unable to stop vomiting symbolized a person unable to overcome the threatening or debilitating situation he was in. This degree of interpretation has not been followed in this chapter or in the remarks by Dr. Wong, who is more interested in the medical condition than in the causes (which are unknown to both of us) of the medical condition.

In the book Fifty Days to Encounter the Five Spirits, each day listed by the yinyang master is designated by one of the combinations of stem and branch. At the conclusion of the booklet, he gives an overview of the characteristics of which shen 神 spirits will respond to the needs of each day according to the branch designation of the day. (Only nine of the ten branch designations are listed.) For example, he writes:

Jia days have always been for the mountain deities [Jiariyuanlai shishanshen 甲日原來是山神]

Yi days will be for the tree spirits [Yiri biding shushen 乙日必定樹神] 


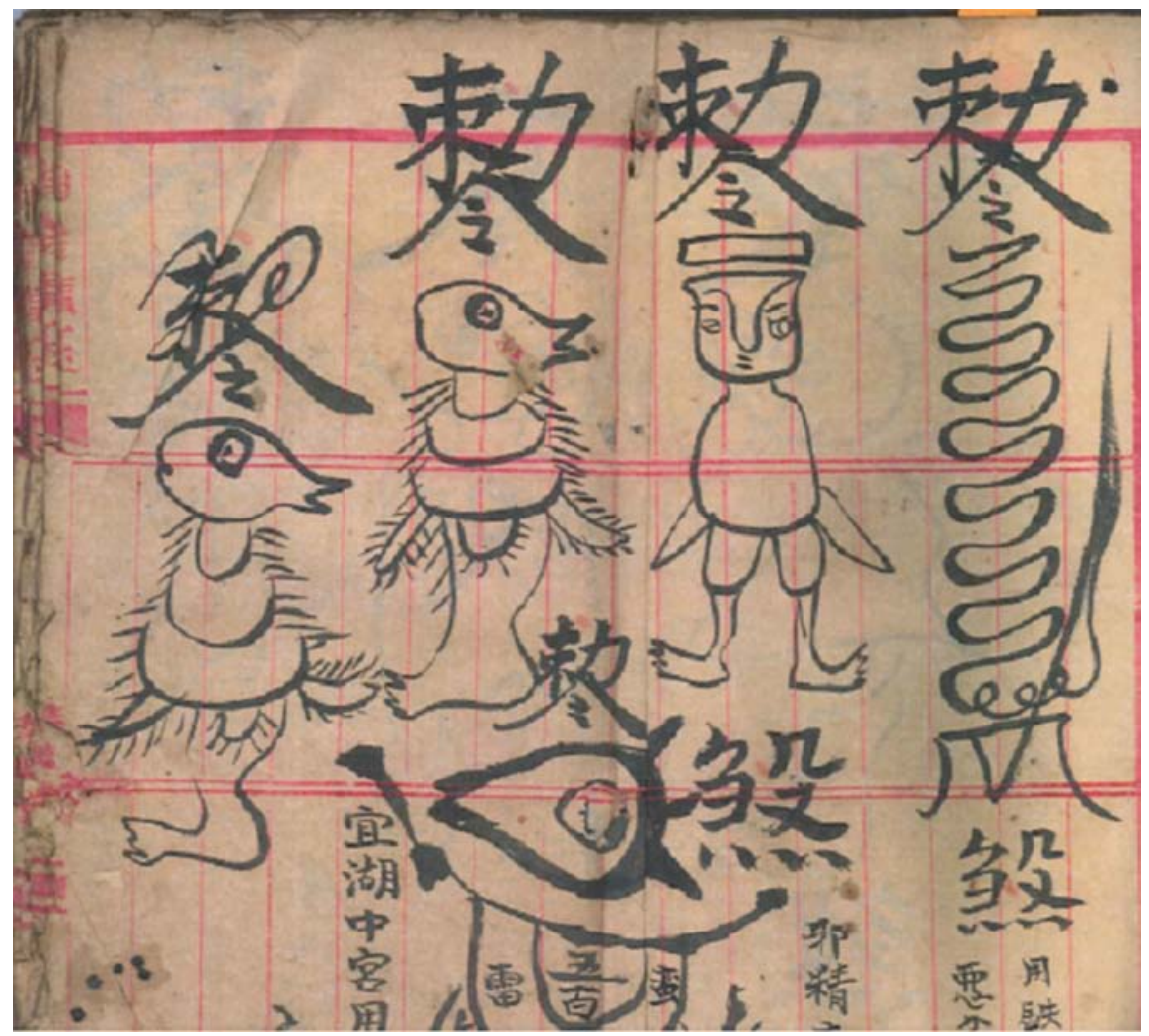

FIGURE 9.6

Petitions to the Thunder Altar [Fengzhi chiling leitan 奉旨敕令雷壇], Page 3, Protection from Evil [sha 憊]. I assigned the title based on the first talismanic character that appears on the first extant page. Drawings of some of the malevolent forces are on pages 2-5. Various spirit generals [shenjiang 神將] are described, along with incantations [zhou 咒] for approaching them to request their help. Based on dates that appear in the text, this was likely written between 1886 and 1900.

PHOTO BY AUTHOR

Bing days will see the kitchen god unable to help [Bingri zaojun dabuli 丙日㿝君大不利]

Ding days will have their calamities crushed by the heaven spirits [Dingri dazai shi tianshen 丁日打災是天神]

Wu days and the land deities sneak around [Wuri chongzuo shi tudi 戊 日崇作是土地]

$Y i$ days are controlled by the Northern Dipper are not propitious [Yiri beidou bujili 乙日北斗不吉利]

Geng days will find the Buddha comes and makes trouble [Gengrifoye lairehuo 庚日佛爺來惹禍] 


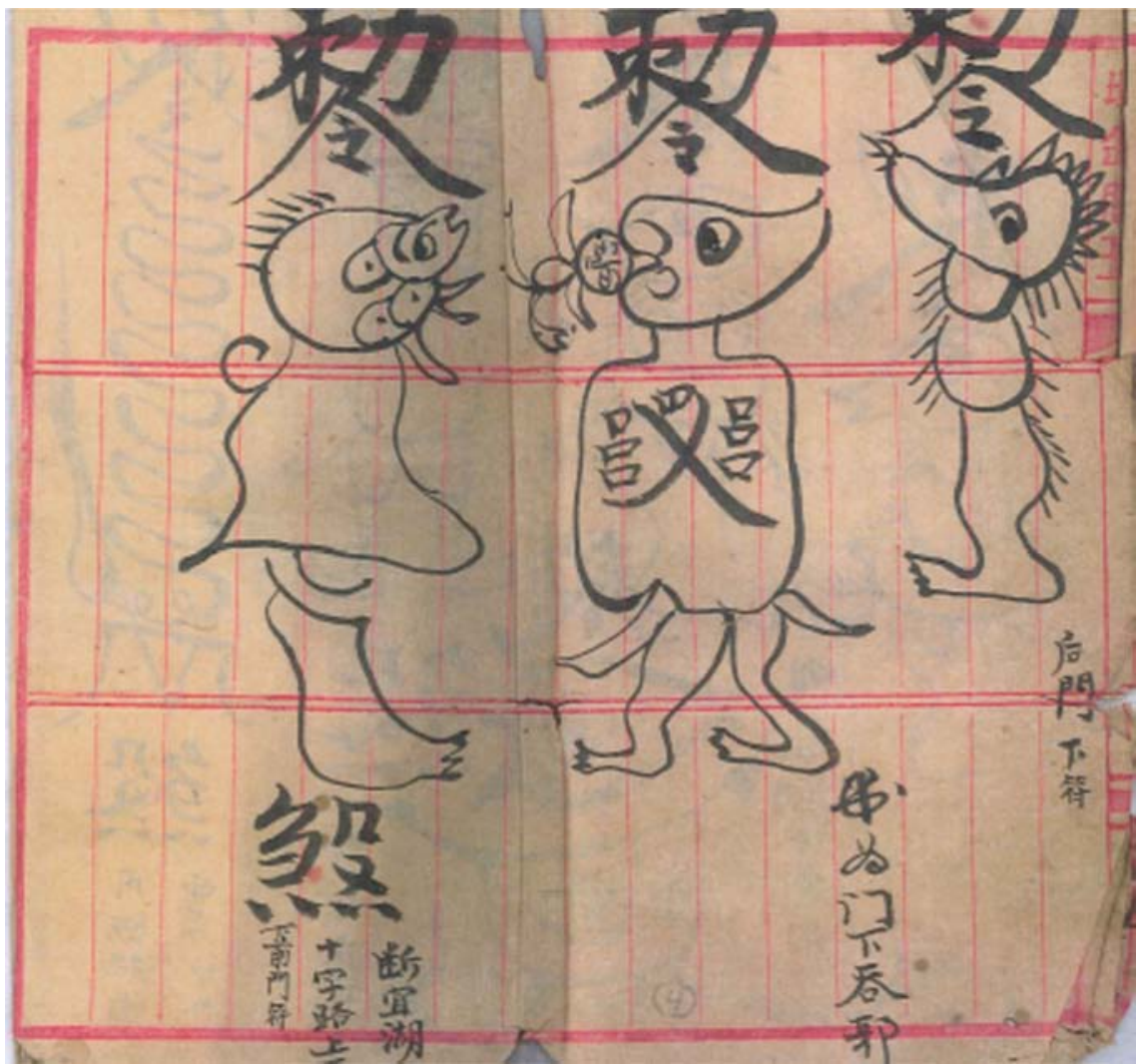

FIGURE 9.7

Petitions to the Thunder Altar [Fengzhi chiling leitan 奉旨敕令雷壇], Page 4, Protection at the Gate. This page shows door or gate evils that can be controlled by the ritual information given in the text. To call on their protection, one can have a talisman prepared; they would not be portrayed in this manner on the door.

PHOTO BY AUTHOR

Xin days will find Guanyin won't leave you [Xinri Guanyin bu lishen 辛 日觀音不離身 $]^{18}$

Ren and gui days are for the five Daoist spirits [Rengui jushi wudaoshen 王癸俱是五道神] (p. 18)

18 Here the word guan 觀 is one word written as mu 目 plus jian 見 (jian 見 on the right side, with the eye radical $m u$ 目 on the left). This is another example of a nonstandard character. 
This step is a further refinement in specifying how certain star spirits [xingshen 星神] and evil forces determine the expected outcomes of each day. It continues to be one of the calculations used by fortunetellers. ${ }^{19}$

\section{Still More Ghosts}

Before we leave this discussion of malevolent ghosts lurking about, let us briefly mention another chaoben dedicated to warning people about these troublesome forces: Incantations to Send Off Ghosts [Songgui chongzhou 送鬼崇咒]. It first introduces the preparations for approaching this sort of trouble, by suggesting that one worship the kitchen god, hang matching couplets for heaven

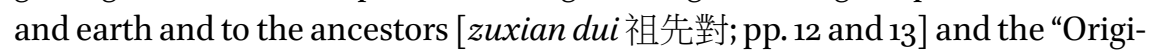
nal Princess of the Jasper Mist," "Sovereign of the Azure Clouds" [Bixiayuanjun 碧霞元君; p. 13]. This beloved maternal figure was extremely popular in Shandong and Taishan 泰山 and in the Beijing area, so we can safely assume this text was prepared in Shandong or Beijing. ${ }^{20}$

The cycle of calendar days and the invading spirit that might be troubling on each day is on pages $14-58$. It begins with the first day of the cycle on page 14, “Jiazi, Metal Element Day" [jiazi jinri 甲子金日]. This yinyang master used a system called "Placing the Sounds and the Elements" [Nayin wuxing 纳音五 行]. It was a way of arranging all the sixty days into thirty pairs. Each pair is put under one of the five elements. So in this case the first two days, the jiazi day and the yichou 乙丑 day, belong to the element metal [ jin 金]. The reference to sound is due to this approach's origin to an ancient theory of music. The system was not used by all fortunetellers or yinyang masters, so in other systems the days are not necessarily attached to a particular element. ${ }^{21}$

The text for this day reads:

Those who become ill on the jia day will not feel calm. They will experience cold and hot flashes; their skin will be flushed. The Ghosts of the Five

19 This aspect of interpreting fortunes can be seen in current horoscopes published in Asia, such as Zhongbaolou tongsheng and Nimaru ichigo Heisei nijüshichinen jingukan kaiunli 2015 .

20 Detailed research on the worship of Bixia yuanjun in the Beijing area is in Susan Naquin, Peking: Temples and City Life, 1400-19oo (Berkeley: University of California Press, 2001).

21 I am indebted to He Wumeng 何無夢 (personal communication, September 2016) for this very clear explanation. The system is laid out well in Yang, Zhuantong wenhua, quanshu, 96-102. 
Roads will come to the home to do mischief, trying to seduce the females and take away their souls. This is because the original request [for help?] has not yet been granted. Quickly face the east and worship the spirit soldiers.

The person who becomes ill on this day will see the Ghosts of the Five Roads, will see spirits, will see ghosts. They will be agitated. It is because someone in the household has committed a transgression. Four malevolent forces are hanging in the room as if a person has died from sickness. The afflicted person has a headache, the heart beats quickly, and there is no appetite. The peak of the illness will come in three, six, or nine days. When the illness is at its worst, worship by reciting the sutra of the kitchen god.

Jiari debing, bu anning. Zuohan, zuore, mianpi qing. Wutong jiaqin laizuohai. Gouyin nv guiwanghunling. Yuanshi jiuyuan weihuanwan; Zhengdong jiqu jishenbing.

Ciri debing, zhuangjian wutong, jianshen, jiangui. Shenshang bu'an. Yin jiazhong dezui, sisha wudiao siguo bingren. Touteng rexin, busi yinshi. Fengsan, liu, jiuri bingzhong. Nian Zao WangJingji.

\section{甲日得病, 不安寧。作寒, 作熱, 面皮清。五通家親來作害; 勾引女 鬼亡魂靈。原是舊愿, 未還完; 正東急去祭神兵。 \\ 此日得病, 撞見五通, 見神, 見鬼。身上不安。因家中得罪。四繁 屋吊死過病人。頭疼熱心, 不思飲食。逢三, 六, 九日病重。念舵王 經祭。}

Like the fifty-day cycle discussed above, this explanation also describes a person afflicted with physical and emotional trauma. The person has fallen into a situation in which the malevolent spirits are angered. A darkness hangs over the environment that can best be lifted by, in this case, calling on the name of the protector of the household, the kitchen god. The explanations for other days in the cycle also prescribe calling on the kitchen god for help, as in the discussion of the gengxu 庚戌 day, which also belong to the metal element (p. 50). The logic behind both of the accounts discussed in this chapter is the same, and the ability of the spirits, malevolent and beneficial, to fight among themselves, is affirmed. ${ }^{22}$

22 Incantations to Send Off Ghosts [Songgui chongzhou 送鬼崇咒] has 112 pages (including partial pages) and is dated 1887. It was copied by Qu Runtian (Qu Runtian ji 曲潤田記, cover, p. 1). All the days in a sixty-day cycle of each of the heavenly stems and earthly 


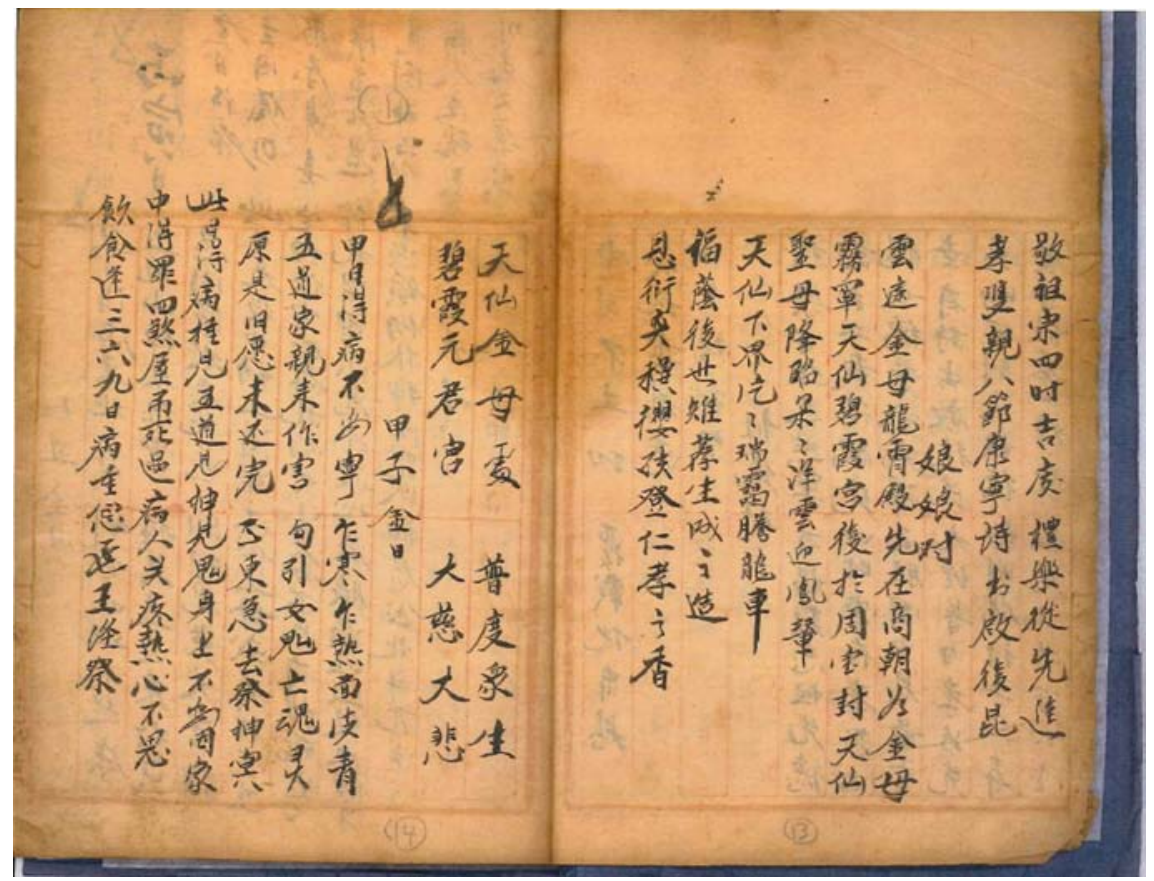

FIGURE 9.8

Incantations to Send Off Ghosts [Songgui chongzhou 送鬼崇咒], Pages 13 and 14, Ghosts of the Five Roads Will Come. A description of trouble on the jia 甲 day is on page 14, in the third vertical line from the right-hand margin. It begins: "Those who become ill on the jia day will not feel calm. They will experience cold and hot flashes, and their skin will be flushed. The Ghosts of the Five Roads will come to the home to do mischief, trying to seduce the females and take away their souls. This is because the original request [ for help?] has not yet been granted. Quickly face toward the East and worship the spirit soldiers" [Jiari debing, bu anning. Zuohan, zuore, mian pi qing. Wutong jiaqin laizuohai. Gouyin nu, guiwanghunling. Yuanshi jiuyuan weihuanwan; Zhengdong jiqu jishenbing 甲日得病, 不安寧。作寒, 作熱, 面皮清。五通家親來作害; 勾引女 鬼亡魂靈。原是舊愿, 未還完; 正東急去祭神兵].

Рното BY AUTHOR

branches are listed, including the symptoms of the afflicted person and the benevolent spirits that can be called upon for help. The book is $73 / 4$ in $(19.68 \mathrm{~cm}) \mathrm{h} \times 6$ in $(15.24 \mathrm{~cm})$ w. I bought it in Beijing in June 2014. Mr. Qu also offered advice on marriage and on the proper couplets to be hung for the occasion. Later on, he told newlyweds how to avoid pregnancy and how to prepare to move house. It appears that after completing the ceremony involving the spirits, he brings up the topic of money. Was it paper money to burn in offering to the spirits, or was it money to be given to the ritual master who has just completed the ceremony? He may have intended the talk on offering spirit money as a way to remind his clients that he would also like to be compensated. In the second 


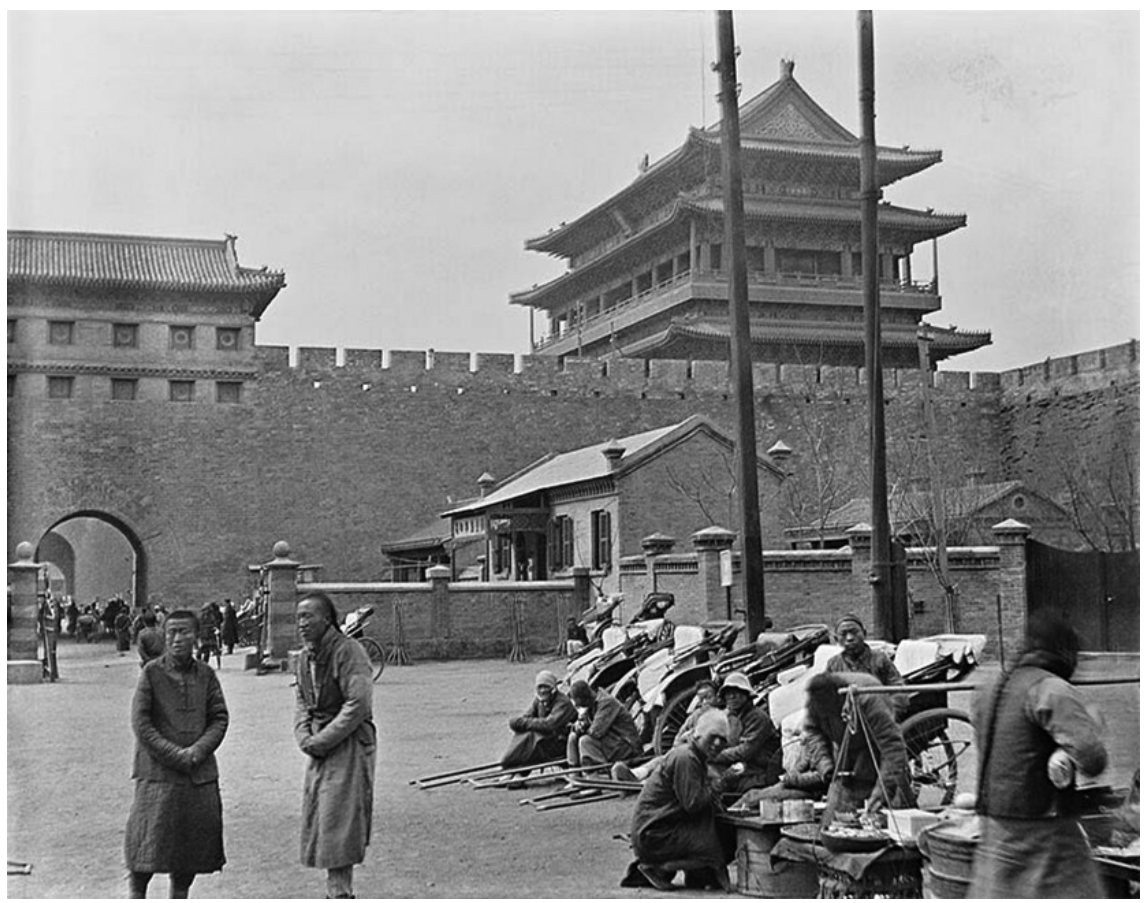

FIGURE 9.9

Rickshaw Pullers Resting. These hard-working common people could easily fall prey to a malevolent force. The evil forces could cause a headache or make the body grow weak, or they could trip the man as he was pulling a customer, resulting in all sorts of troubles. The photo shows the inner gate of the Qianmen Gate 前門 complex in Beijing. The official name of the gate was the Zhengyangmen 正陽 門.

PHOTO: RICKSHAW PULLERS AT CHIEN MEN, BEIJING, 1914; PHOTO: WILLIAM LEETE; RESTORATION AND PRINT @ 2016 WILLIAM MORSE. USED BY SPECIAL PERMISSION

\section{Conclusion}

The spaces inhabited by the supernatural were in the Heavens above and in Hell below, but it was also in this world of human beings. In the Heavens, the highest spirits were impassive, ruling through their majesty and vast powers. In Hell below the earth, the ghosts and demons carried out the punishments that had been allotted to souls who in life had transgressed the accepted

half of the booklet, he repeats some of the couplets he recorded on earlier pages and, in some cases, writes down additional couplet texts. A number of riddles are on pp. 86-96; pp. 103-112 return to the topic of advice for people on writing polite letters to relatives. 


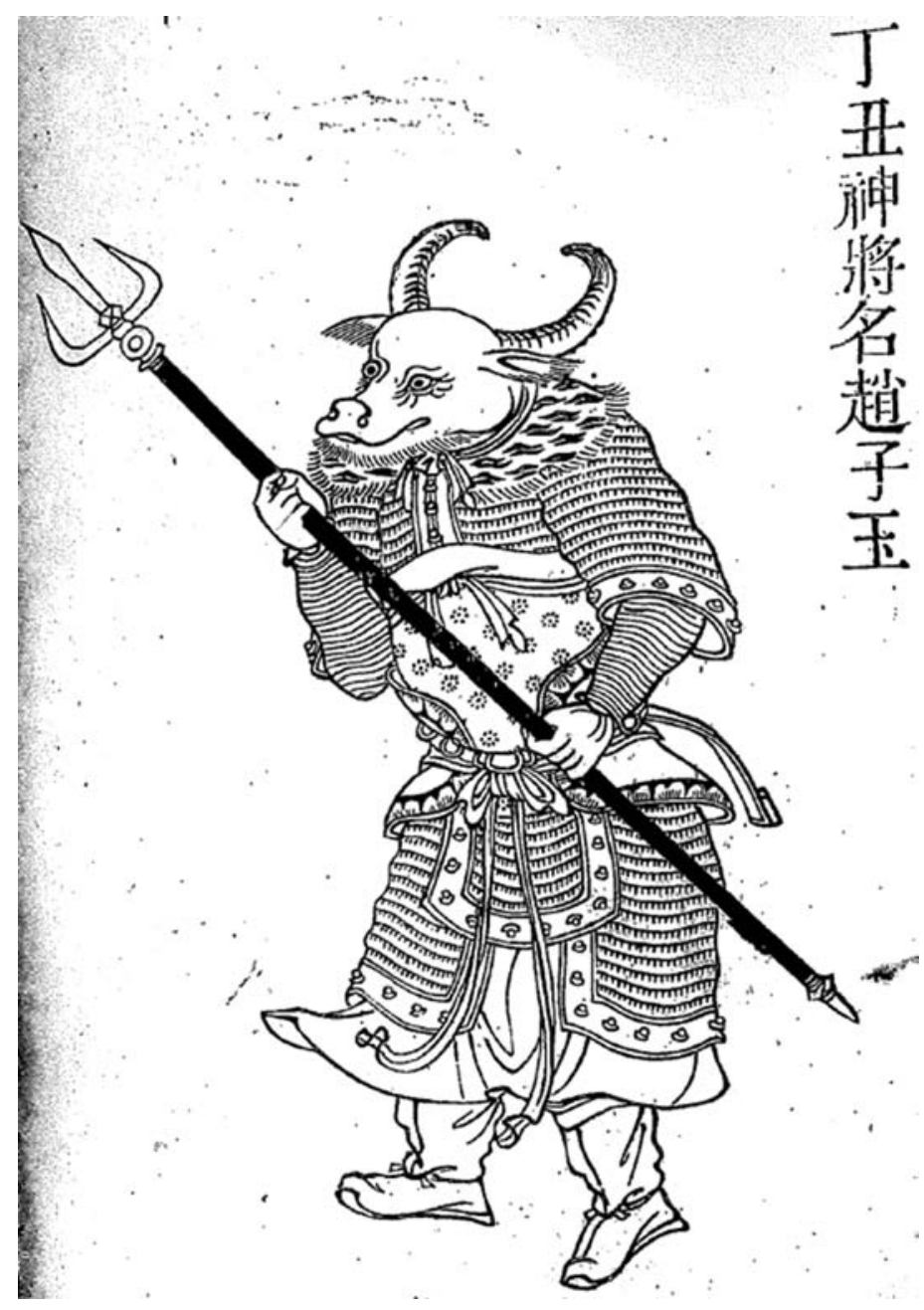

FIGURE 9.10

The Dingchou Spirit General Named Zhao Ziyu [Dingchou shenjiang ming Zhao Ziyu 丁丑神將 名趙子玉]. His designation, Dingchou, comes from the system of ten heavenly stems [tian'gan 天 干] and twelve earthly branches [dizhi 地支] usually used to mark the cycles of days and years. He is considered to be associated with the powerful group known as the Spirit Generals of the Six Jia and Six Ding [Liujia liuding shenjiang 六甲六丁神將]. He commands numerous ghost soldiers [yinbing 陰兵] and can be called upon using special talismans to confront evil and malevolent forces. He is said to be under the command of the Perfected Warrior Great Emperor [Zhenwu dadi 真武大帝]. The origional illustration was published in the Collection of Ancient and Current Illustrations [Gujin tushu jicheng 古今圖書集成] section on spirits and the supernatural [shenyi dian 神異典], vol. 32, printed in the early 1700 s.

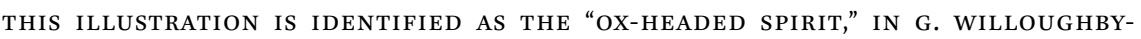
MEADE, CHINESE GHOULS AND GOBLINS (NEW YORK: FREDERICK A. STOKES COMPANY, 1926 [?]), FOLLOWING P. 74 


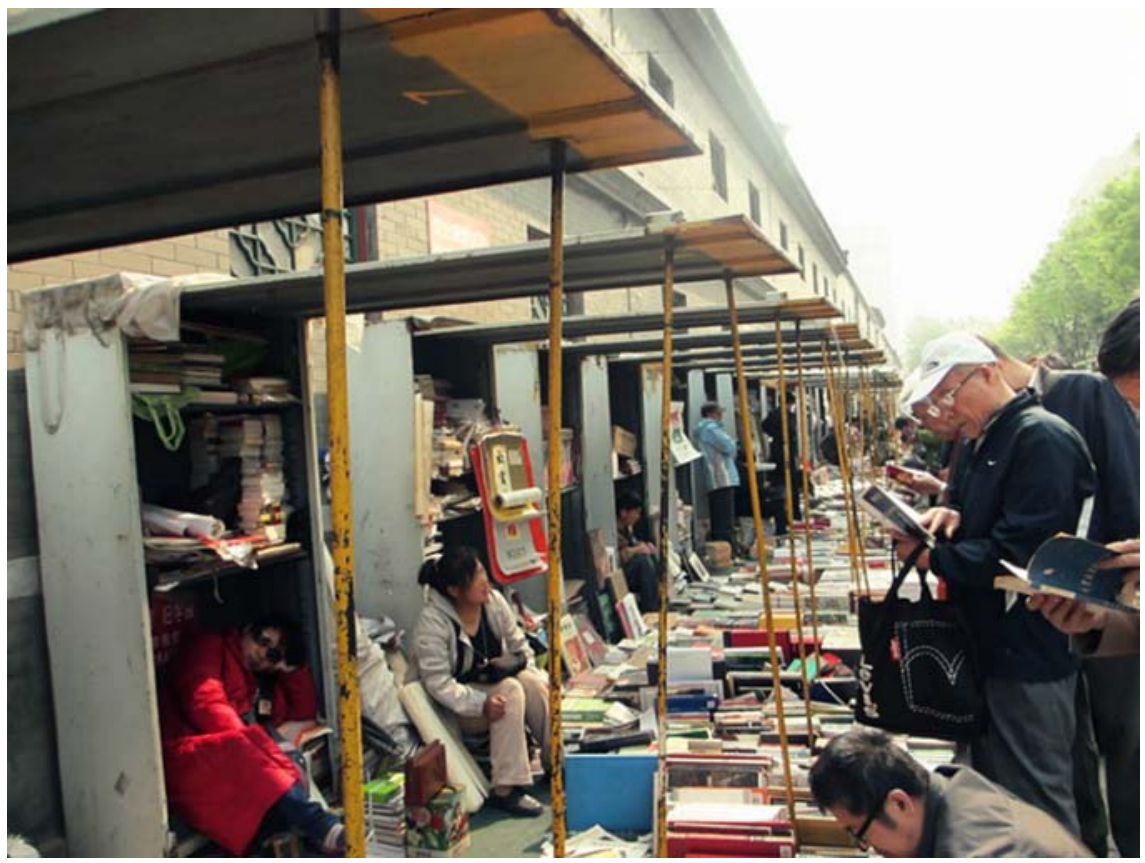

FIGURE 9.11

Panjiayuan Antiques Market in Beijing. Beijing's Panjiayuan Antiques Market [Panjiayuan jiuhuo shichang 潘家園舊貨市場], which opened in the early 199os, is where many of the chaoben used in this book were purchased. Although filled with replicas of antiques, most of the chaoben and old documents for sale are authentic. The section of the market in this photo is one area where books and printed matter are for sale.

TAKEN FROM THE BLOG OF WEI LIMIN 魏利民, PARTIALLY TITLED “GATHERING THE WIND, RARE TREASURES FROM THE PANJIAYUAN MARKET" [CAIFENG DAO BEIJING PANJIAYUAN JUIHUO SHICHANG LAI TAOBAO 采風到北京潘家園舊貨市場來淘寶], AT HTTP:// BLOG.163.COM/WEILIMINOK@126/BLOG/STATIC/7198781320134784346594/. ACCESSED 7 MAY 2013

morality. The ghosts could interact with the spirits of the middle rank or lower because in Hell the lower-rank spirits supervised the ghosts. On earth, ghosts and goblins could move about to vex and frighten hapless human beings. Daily tasks were difficult when some angry demon caused a headache or loss of energy. In popular stories circulated during the Qing and the Republic, ghosts could actually cause human beings to die. In the handwritten text Fifty Days to Encounter the Five Spirits discussed above, the ghosts could trouble hardworking peasants in all sorts of ways.

While I was still a student studying in Taiwan in the 196os, I collected information by asking people I met to tell me about their experiences with ghosts. I learned about the ghosts, goblins, and demons that the Daoist deities 


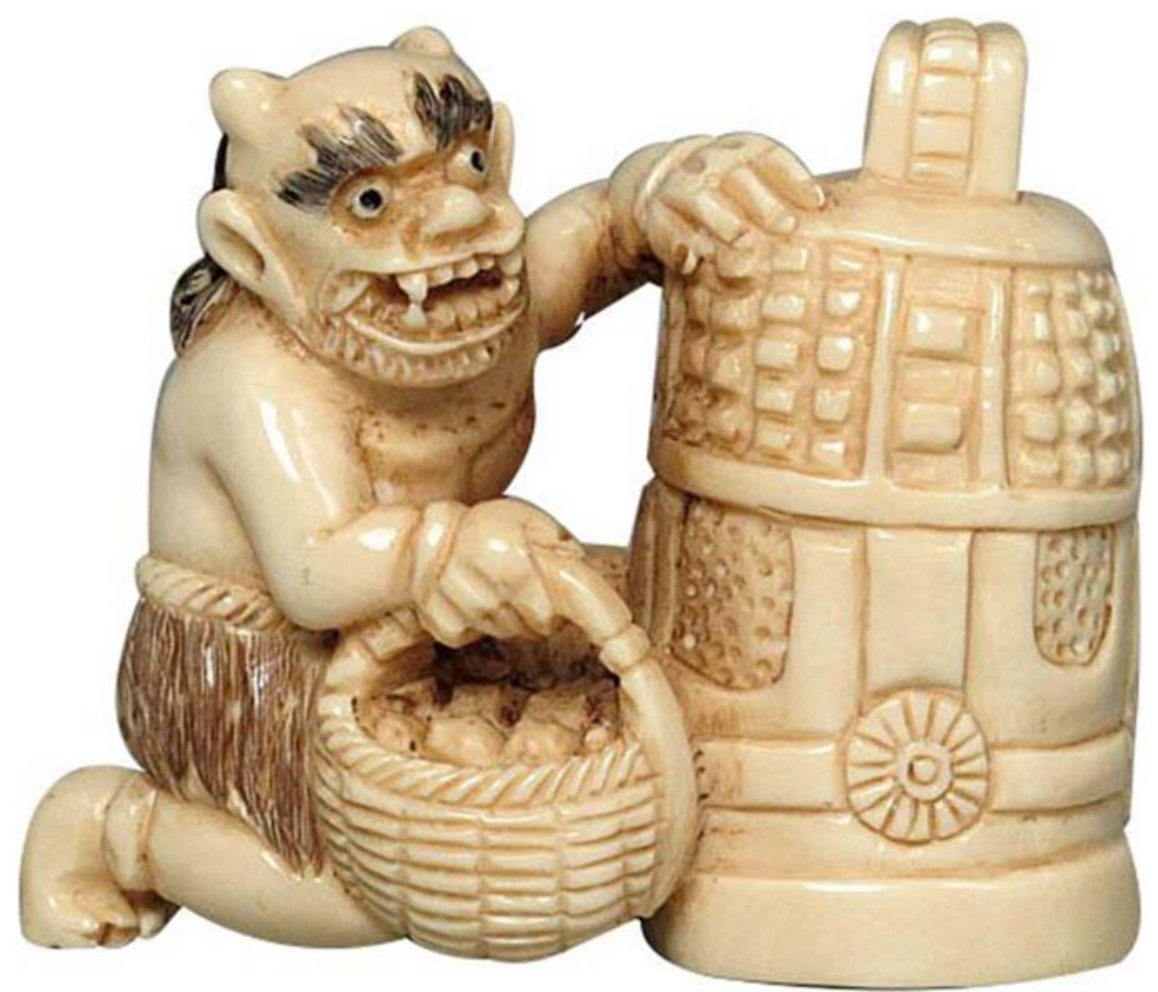

FIGURE 9.12

Japanese Image of a Goblin. This is an ivorynetsuke 根付け figurine from Japan, less than 2 inches tall. It depicts the scary countenance of a goblin and resembles descriptions of them in Chineselanguage sources.

THIS PHOTO IS IDENTIFIED AS "MAMMOTH IVORY NETSUKE HANDCRAFTED JAPANESE

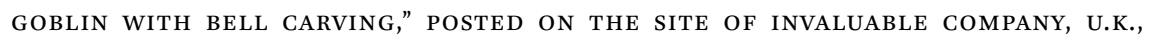
PREMIER AUCTIONS AND GALLERIES IN NOVEMBER 2015, HTTP://WWW.INVALUABLE.CO .UK/INVALUABLE/HELP.CFM

could control and banish with their spirit generals and spirit troops [shenbing 神兵]. In 1967, I had a conversation about ghosts with our amah 阿媽 (a maid and cook in our house; this is a polite form of address for an elderly woman, although our amah was in her thirties). She was a woman from Hunan with almost no formal education and had come to Taiwan with her husband in the late 1940s with the Nationalist forces. Here is what she told me (April 1967, in Taipei):

When I was about twelve or thirteen years old, near the city of Hankou 漢 $\square$, I saw a sick man lying in a nearby house that was not lived in regularly, and his room was bare. At one point, he began gasping as if he would die. 


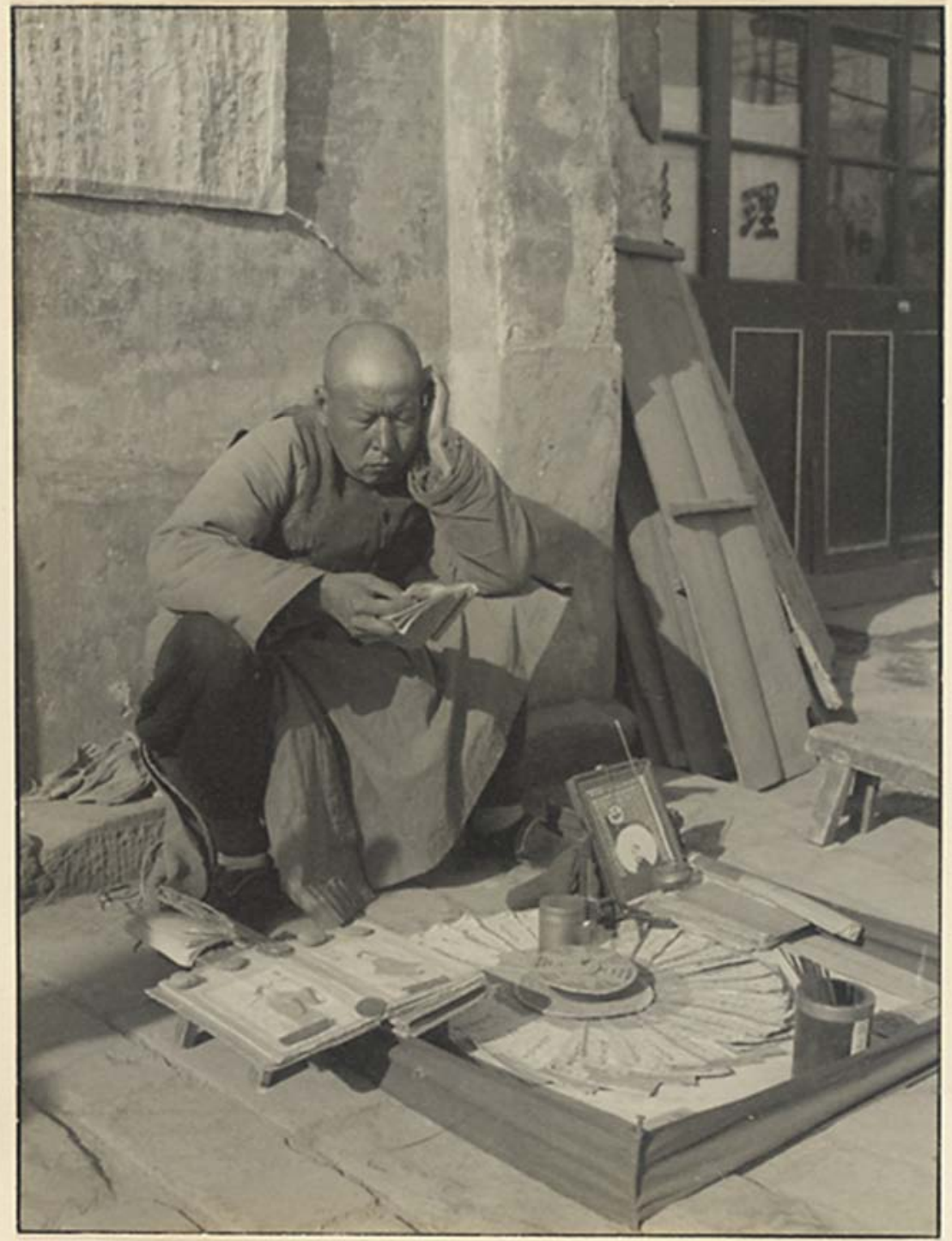

1661

FIGURE 9.13

Beijing Fortuneteller. By sitting in public with his "tools" laid out before him, this fortuneteller was advertising his trade and his availability to the public. He did not need a banner or shop sign, and, weather permitting, he did not even need a shop. The photo was taken by Hedda H. Morrison (19o81991), likely in the 1930s. Morrison was born in Germany and lived and worked as a photographer in Beijing from 1933 to 1946.

PHOTO FROM THE HEDDA MORRISON PHOTOGRAPHS OF CHINA COLLECTION AT THE HARVARD-YENCHING LIBRARY 
My young friends and I went into the room, and the man told us to look up at one of the windows high on the wall, saying he had seen a ghost there.

Our amah became very frightened because she saw it, too. It was the face of a Chinese man wearing a Chinese army cap. Her friends all hugged one another, and then they ran out of the room, where our amah became dizzy and almost fainted. Her grandfather put her to bed, but none of her little friends had seen the ghost. Later, when she and the sick man compared what they had seen, they realized they had both seen the same image. Our amah called the apparition a ghost soldier. In talking about this with me, she said she had no idea where the ghost came from or why. I asked her if she ever went to a temple to pray, and she said she had no religious beliefs, except that she believed in ghosts because she had seen one.

Our amah made further comments on ghosts the following day: "There are many types of ghosts, such as male and female ghosts [nanguinügui 男鬼女鬼], and they live on a certain spot of land. If someone disturbs them, then they will come to bother that person. They can see you, though you usually cannot see or hear them."

On the mainland, her uncle had the ability to see these ghosts or at least to distinguish their sounds. Sometimes, while walking along, he would sense one ahead and make a wide circle to avoid them. If a ghost comes to you, you should consult a Daoist master, and he will tell you what type of article will propitiate the ghost. Perhaps you can burn some money or other articles for him. Female ghosts often want some nice clothes or such. In the old days, some ghosts would want articles connected with opium smoking, so these goods had to be bought and “burned for the ghost” [shaogei ta 燒給他]. "Many of the young people don't believe in ghosts and none of the younger people do. But I definitely believe in them."

She told me that the second time she saw a ghost was a few years earlier, while living in Banqiao 板橋, Taiwan, in the 195os. One evening, high up in one of the windows, she saw the face of a very pretty young boy; she could not see his body or the top of his head. She knew it was a male ghost because no person is that tall, and there was no way for a normal person to climb up so high as to reach that window. Her friends told her it had been a thief, but she knew it had really been a ghost. The next day she bought some paper money [jinzi 金子] and burned it outside her house. She could not remember the amount of the money but it was "several score of bills" [shiji yuanqian 十幾元錢]. She went on to say that people usually just happen to run into ghosts if their "luck is bad” [yunbuhao 運不好], and then they should offer something to the spirit. 
If a person is walking along and bumps into a ghost, he will "fall down dead" [sidaole 死倒了]. If your luck is good or you avoid them, they will not trouble you. Usually, they trouble you only because you have disturbed them, because the area was originally theirs.

These ideas about ever-present ghosts persist in China. In 2012 the American writer Michael Meyer spent a year living in the village of Wasteland [Huangdi 荒地] in Jilin Province. One day, he visited a home where a funeral was being held. Outside the home, Meyer encountered one of his middle-school students. Meyer described the encounter:

"Let's go," the boy urged, "before the ghost attaches itself to you." "What about you?" I said. "Why wouldn't the ghost cling to you?" "I'm a kid! the boy yelled." "So what? Do ghosts hate homework? They don't want to go through school again?" The boy pulled my arm and said, "Stop joking. We have to move, before it's too late." He handed me the umbrella, and we huddled beneath it on the walk to his house. ${ }^{23}$

The amah's words and the boy's fears, along with the catalogue presented in the Fifty Days to Encounter the Five Spirits chaoben discussed above, sum up concisely the popular perceptions held by the common people in China, then and today. The troublesome ghosts could be anywhere, lurking unseen to interfere with human activity. Best to avoid them if possible, propitiate them with spirit money or other offerings when necessary, and chase them away when you know their names and can discover their hiding place.

This chapter uses the chaoben I collected as a way to illustrate the perceptions and involvements of the common people in China from the late Qing (1876 is the earliest dated manuscript discussed in this chapter) to 1967 (when I interviewed our amah in Taiwan), then to the account I read in 2015. The popular religious activities in Taiwan, Hong Kong, and Singapore and being revived in China indicate that the same religious approaches as discussed in this chapter are used to deal with issues involving the supernatural today.

The approach of many people until the end of the Republican period was to manually copy a religious text in order to gain merit with the deities in the Heavens. In addition, ritual specialists compiled information about the deities and ghosts, as we examine here in Secret Text for Summoning the Snake and Fifty Days to Encounter the Five Spirits. They may have had printed materials

23 Michael Meyer, In Manchuria: A Village Called Wasteland and the Transformation of Rural China (New York: Bloomsbury Press, 2015), 259-26o. 
or other handwritten texts available to them, because their purpose was to pass on practices that were effective when dealing with ghosts; they were not permitted to be inventive or alter the text they were copying. But in these cases, unlike in accepted Daoist or Buddhist works, the materials they may have copied from were not part of any standard textual corpus, so we cannot verify them against a standard or authorized version; instead, we need to rely on the handwritten versions we have as authentic representations of their views.

The large number of hand-copied books by ritual specialists currently available in the markets in China indicate that involvement with the deities and ghosts among the common people was extensive during the late Qing and Republic. The pingmin in China perpetuated a highly symbolic culture involving gods and ghosts. They put their talents and energies together to help their fellow humans gain blessings from the deities and to control the troublesome ghosts that bullied them. We can only fully understand the lives of the common people of China in the period studied in this book if we take into account and give a place of prominence to the tradition of "popular religion," which formed their perceptions of the realms of deities and spirits. The supernatural was a part of their lives. It materialized in every community celebration held during the calendrical cycle, in every small shrine or imposing temple such as appeared throughout the country.

Springing forth from the grand vision of the forces that ordered life and death came the ghosts and goblins that interfered with one's life in a very personal and intimate way, such as vomiting, a headache, or dizziness. The troublesome spirits were a logical extension of the grander vision of august deities. The troublesome spirits brought the powers of the spirit world down to the level of the individual. At that level, the individual pingmin constructed a symbolic and physical world that was immediately understandable and relevant to them. 